\title{
TEACHING DIGITAL LITERACY: TOOLS AND TECHNIQUES FOR CLASSROOM
}

\author{
Stephy K Sunny1, Dr. K Ramasamy ${ }^{2}$ \\ ${ }^{1}$ Research Scholar, Mother Teresa Women's University, Kodaikanal, Tamil Nadu \\ $\mathcal{E}$ Librarian, Sacred Heart College, Chalakudy, Thrissur, Kerala \\ Email: stephyk.sunny@gmail.com \\ ${ }^{2}$ College Librarian, M. V. Muthiah Govt. Arts College for Women, Dindigul, Tamil Nadu
}

\begin{abstract}
Manuscript Info
Manuscript History

Received: 03 February 2021

Final Accepted: 22 March 2021

Published: 10 April 2021

Online Published: May 2021

DOI: http:/ /dx.doi.org/10.35337/EIJLITR.2021.1502

(C) Stephy K Sunny, Dr. K Ramasamy The Author. This is an open access article under the terms of the Creative Commons Attribution License 4.0, which allows use, distribution and reproduction in any medium, provided the original work is properly cited.
\end{abstract}

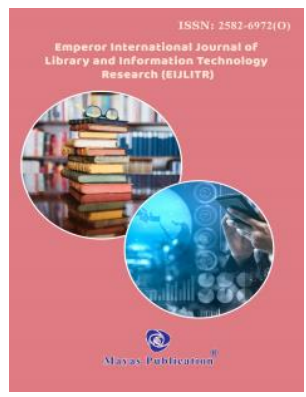

\section{Abstract}

Electronic learning has gotten the new average for 21st century understudies. Despite the way that understudies are putting more energy in the electronic space it isn't needed that they are progressed literates. Mechanized capability is a principal capacity expected to make due in the present progressed world. This underlines the need to show electronic schooling to understudies. As new age understudies are producers and clients of automated substance, it is central for them to have extraordinary resource schooling, search and evaluation capacities and care about thoughts like advanced security, copyright, etc isolated from having sound inventive capacities. Progressed capability help understudies with partner with their mechanized world suitably and help them with ending up being profound established understudies. Schools should endeavor to join thoughts like progressed capability in the instructive arrangement close by standard subjects to meet the changing necessities of forefront understudies. As such identical opportunity can be given to all of the understudies to accomplish these capacities and vanquish the high level division. Diverse devices and headways are existing and new ones are coming up ordinary which help in showing mechanized schooling. Instructors should keep themselves revived about latest headways and endeavor to use different strategies to make electronic capability getting the hang of entrancing. Planning understudies since from the beginning can help them with adjusting up to the consistently changing progressed world. 
Keywords:: Digital Literacy, Digital Literacy Teaching, Classroom training, Digital Skills, School Students.

\section{INTRODUCTION}

The current children are progressed local people who are normally acquainted with the modernized world. They approach advancement from an energetic age. The scene of pandemics and trademark fiascoes in the new past has disturbed school guidance system to online mode. From PDAs being limited at schools to govt. giving flexible and TV to understudies for enlightening purposes, the world has acknowledged this high level shift. Online learning has gotten the new common for 21st century understudies. In light of extended permission to mobile phones and availability of quick web affiliation, understudies are putting more energy in the high level space for entertainment and educational purposes. Nevertheless, extended induction doesn't actually make them mechanized literates. The regular IT getting ready gave in numerous schools may not be adequate to help understudies with performing incredible in the high level environment. This anxieties the prerequisite for schools to show progressed capability to understudies. Gen $\mathrm{Z}$ faces different troubles actually as they are generously more revealed and advanced. Hence, showing them a comparable course as late school graduates won't be adequate. Various gadgets and techniques are available to urge mechanized instruction peculiarly to understudies. The current preparing system should endeavor to consolidate novel thoughts like automated training in the school instructive program close by standard subjects, to meet the changing prerequisites of front line understudies. Such a change is inevitable in making cautiously careful and talented occupants for what's to come.

\section{Digital Literacy}

Progressed Literacy is the care, attitude and limit of individuals to reasonably use mechanized mechanical assemblies and workplaces to recognize, access, manage, arrange, evaluate, inspect and join progressed resources, foster new data, make media explanations, and talk with others, concerning unequivocal life conditions, to enable important social action; and to consider this cycle. Progressed capability is seen as a principal capacity comparably as schooling and numeracy (Martin and Grudziecki, 2006). Pinnacles and Bartlett (2012) composed the distinctive mental and social cycles related with electronic capability into three classes: finding and eating up cutting edge substance, making modernized substance, and passing on cutting edge substance. A mechanized capable individual will have the abilities to perceive the prerequisite for cutting edge information, can use fitting chase strategies to track down the vital information from a reasonable source, will really need to essentially survey the quality and validness of the recuperated progressed information, make progressed substance carefully, use web 2.0 instruments and related developments safely and successfully and pass on electronic information ethically with an appreciation of genuine points of view.

\section{Digital Literacy Teaching in School}

The world is changing and the piece of automated headways in normal day by day presence is growing. "Electronic capacity is both an essential and an advantage of inhabitants, if they are to be pragmatic in the current society" (Ferrari, 2012, p.3). New age understudies are producers and customers of modernized substance. Accordingly, it is key for them to have extraordinary resource capability, search and evaluation capacities and care about thoughts like advanced security, copyright, etc isolated from having sound imaginative capacities. It includes concern when the understudies are constantly busy with the advanced world without being completely instructed about its various perspectives. Along these lines, they should be set up in these capacities to set them up for future challenges. Modernized training helps understudies with helping out their high level world effectively and help them become enduring understudies. Kristen Cole (2019) is of the evaluation that development has and is pushing our existence ahead at a quick speed. Enormous quantities of the places that are available for understudies after they graduate are presently being electronic. A consistently expanding number of occupations require the delegates to have a working data on fundamental advancement. Helping understudies with remaining mindful of development is significant for high level training planning. 
The mission of schools is to help understudies in getting data, theoretical just as for valuable life moreover. Adding high level training to the school instructive program plan understudies to be competent adults, be powerful in their callings and gotten extraordinary mechanized occupant. Though various understudies today are instructed and approach mechanical contraptions, web, etc, many need data about cutting edge citizenship. Through high level training getting ready, schools can tell understudies the best way to act and ensure prosperity while simultaneously interfacing with the electronic neighborhood. As the occurrences of cyberbullying and various cybercrimes are growing, schools can make care among understudies and set them up to painstakingly oversee such issues. Automated capability capacities can vary among understudies in light of cutting edge hole. By giving electronic capability getting ready, schools can give identical opportunity to all of the understudies to achieve these capacities. This can help understudies from under unique regions to be likewise prepared as others and vanquished the high level detachment. Understudies consistently use development for entertainment and enlightening purposes and are vulnerable to trickiness and fake news. By far most of them don't think about the need to evaluate progressed information and don't give fitting credits while using others' contemplations. In fact, even understudies at school and school level are found doing copy stick for their undertakings and adventures as they are shown simply ordinary subjects and are not set up in these perspectives. Thusly, it is essential to educate understudies about thoughts like artistic robbery, copyrights, alluding to, etc from a young age. Schools can accept a significant part in giving this data. The current understudies have a huge load of receptiveness and opportunity to use mechanized development for content creation and facilitated exertion. Kristen Cole (2019) says that instead of holding adolescents back from interfacing imaginatively with development, an accentuation on high level training in the homeroom can help them with developing and widen their usage of advancement for creative mind and self-verbalization and to cultivate a more noticeable appreciation of the complexities of what they're doing.

\section{Techniques for Teaching Digital Literacy in School}

Preparing high level training in the homeroom can be a troublesome endeavor. Possibly than showing simply the theoretical perspectives, schools can focus in extra on suitable orchestrated educational courses which can be of better use for understudies. Marianne Stenger(2018) says that the current understudies are presently powerful through online media, and usually they are more adept at using it than their teachers. So the consideration shouldn't be on familiarizing understudies with the complicated subtleties of electronic media, yet on displaying how it might be used in an informational setting. They can moreover be shown interference the board strategies including taking tech breaks for the length of the day, calming sees while analyzing, etc The current understudies will undoubtedly expect that their data is taken care of on the web, and thusly, may not actually consider to protecting their security and be as mindful in their online relationship as they would be eye to eye. They can be made careful about the adverse consequences of this and can be instructed to build a positive progressed character which can be monstrously favorable to their livelihood prospects. Sorting out some way to ensure security on the web yet likewise how to share the right information and substance are critical pieces of a fair progressed capability preparing.

Understudies can be given major preparing about using contraptions like mobile phones, workstations, etc and their various functionalities. As understudies come from different establishments and may have assorted progressed capacities, bundle activities can make them acquire from each other and improve their capacities. Through electronic instruction planning, understudies can be offered opportunity to make and share their innovative progressed substance. Workshops and challenges can be driven for understudies to display their endowments. They can in like manner work on building their own locales and applications or even collaborate with others to compose entrancing musings. Understudies can be given sensible getting ready for surveying information sources and can be requested to give references and do artistic burglary check for undertakings and exercises. Hague and Payton (2011) are of the appraisal that also as understudies work on arrangement across all school subjects, not simply in unequivocal English activities, so should understudies make modernized capability practices in all subjects, including ICT. 


\section{Tools for Teaching Digital Literacy in School}

There are some principal advancement necessities for starting automated instruction program in schools. Broadband affiliation and contraptions like tablets, work stations or PCs required for each understudy. Different instruments are available for showing mechanized capability that teachers can research as they cultivate their method and exercise plans. A part of these gadgets are:

Good instinct Education: Common Sense is a non-advantage affiliation focused on improving mechanized capability among youths. They give free progressed citizenship instructive arrangement to K-12 understudies. A couple of learning practices are available to understudies subject to their assessment and level so they can assume liability for own high level lives. It offers start to finish reviews by experts to help teachers track down the advantage application, game or site for the investigation corridor. They have practice plans, quick activities, toolboxs, homeroom chronicles and various games for understudies to make progressed capability getting fascinating (Digital Citizenship Curriculum, n.d.).

Imaginative Commons: It is a non-advantage affiliation that beats legitimate hindrances to the sharing of data and imaginativeness. It is a site that allows the opportunity to exchange information without worrying about secured material. It has chronicles and explanation of ensured materials and open informational resources. Teachers can use this site to support understudies about copyright and how to pick the best license for their imaginative work (Creative Commons, n.d.).

Scholarly robbery Checker Websites: Plagiarized forming is uncommonly essential with understudies. To prevent this, instructors can familiarize understudies with locales like Grammarly, Dupli Checker, Plagiarism finder, etc which are free destinations that licenses anyone to move reports successfully which are then sifted to check for imitated work. Understudies can be told to use these locales and check their undertakings and various works for duplicated content.

Reference Manger: Students can be familiar with reference creation locales like Easybib, Scribbr, Zoterobib, etc so they make rundown of sources adequately for their works. Such planning can be valuable to understudies to become good experts later on.

Microsoft Digital Literacy Curriculum: Through an extent of free online almost immediately courses, it plans to show the fundamentals of using progressed advancements and help to investigate the mechanized world safely and surely. Microsoft Digital Literacy offers resources, including SCORM packs, practice guides, records, chronicles, and shut engraving reports. Educators can use this to design their high level training course.

Content creation gadgets: There are various applications and programming to make electronic substance like chronicles, progressed stories, exuberance, etc Understudies can be told about the usage of some notable devices like Adobe Slate, Bubblr, Windows Movie Maker, Microsoft's Photo Story, Apple's iMovie, etc Understudies can be given different endeavors to make content using these instruments.

\section{CONCLUSION}

Instruction today goes past learning standard subjects in homerooms. Being modernized capable is the need critical as by far most of the positions today demand cautiously gifted laborers. So the schools should start focusing in on including high level training activities to help understudies with making capacities for the new age. Various instruments and developments are coming up conventionally to overhaul progressed capacities of people. Instructors should keep themselves invigorated about latest developments and endeavor to educate understudies. Preparing understudies since from the get-go through high level training tasks can help them with adjusting up to the continually changing electronic world. The current world has better degree for some eccentric occupations like youtubers, bloggers, specialists, etc By getting progressed capability capacities, understudies can recognize their potential in these fields and encourage their capacities from a starting stage. In like manner, modernized instruction can make the understudies fundamental researchers and able progressed occupants. 


\section{REFERENCE}

1. Creative Commons. (n.d.) https://creativecommons.org/

2. Digital Citizenship Curriculum. (n.d.). Common Sense Education https://www.commonsense.org/education/digital-citizenship/curriculum

3. Ferrari, A. (2012). Digital competence in practice: An analysis of frameworks. Sevilla: JRC IPTS. https://op.europa.eu/en/publication-detail/-/publication/2547ebf4-bd21-46e8-88e9 /languageen

4. Hague, C. \& Payton, S. (2011). Digital literacy across the curriculum. Curriculum \& Leadership Journal .9 (10). http://www.curriculum.edu.au/leader/default.asp?id=33211\&issueID=12380

5. https://www.fi.ncsu.edu/wp-content/uploads/media/media/2013/05/digital-literacies-andlearning.pdf.

6. Kavitha, R and Aravind, S (2021), Information Seeking Behaviour Through Internet Technology in Library Users, Chidambaram Town. Emperor International Journal of Library and Information Technology Research, 1(1), 16-23.

7. Kristen Cole. (2019, May 23). The Epic Guide to Digital Literacy in Education. Schoology. https://www.schoology.com/blog/epic-guide-digital-literacy-education

8. Marianne Stenger. (2018, October 22). 7 Ways to Teach Digital Literacy. informEd. https://www.opencolleges.edu.au/informed/edtech-integration/7-ways-teach-digital-literacy/

9. Martin, A., \& Grudziecki, J. (2006). DigEuLit: Concepts and tools for digital literacy development. Innovation in Teaching and Learning in Information and Computer Sciences, 5(4), 249-267. https://www.tandfonline.com/doi/full/10.11120/ital.2006.05040249

10. Pratheepan, T and Jayakananthan,M ( 2021), Application of Google Analytics Model for Evaluating the Visibility of Library Web Portals of the UVA WELLASSA University, Sri Lanka. Emperor International Journal of Library and Information Technology Research, 1(1), 24-36.

11. Spires, H. A., \& Bartlett, M. E. (2012). Digital literacies and learning: Designing a path forward. NC State University. 